\title{
STRATEGI KOMUNIKASI DALAM MENINGKATKAN KINERJA KARYAWAN DI BHR LAW OFFICE
}

\author{
Oleh: \\ Ni Luh Putu Sariani \\ Universitas Pendidikan Nasional (Undiknas) Denpasar \\ putusariani@undiknas.ac.id
}

\begin{abstract}
ABSTRAK
Strategi Komunikasi dalam meningkatkan Kinerja Karyawan di BHR Law Office. Tujuan dari penelitian ini ialah untuk mengetahui strategi komunikasi dalam meningkatkan kinerja karyawan di BHR Law Office. Penelitian ini menggunakan Teknik analisis data deskriptif kualitatif. Adapun Teknik pengumpulan data berupa observasi (pengamatan), dokumentasi (bahan-bahan yang langsung dari lapangan), serta wawancara kepada pimpinan dan karyawan BHR Law Office. Berdasarkan hasil penelitian menyimpulkan bahwa komunikasi adalah hal yang mengikat kesatuan perusahaan. Berkomunikasi dengan baik dalam sebuah perusahaan tidaklah mudah. Strategi komunikasi perusahaan dibutuhkan untuk meningkatkan kinerja karyawan, dimana BHR Law Office menerapkan strategi komunikasi yang menekankan kepada pesan komunikasi verbal dan komunikasi non verbal.
\end{abstract}

Kata kunci: strategi, komunikasi, kinerja karyawan.

\section{ABSTRACT}

The communication strategy in improving employee performance at the BHR Law Office. The purpose of this study was to determine the communication strategy in improving employee performance at the BHR Law Office. This study use descriptive qualitative data analysis techniques. The data collection techniques are in the form of observations, documentation (materials directly from the field), and interviews with the leaders and employees of the BHR Law Office. Based on this research it can be concluded that communication is a binding matter for corporate unity. Well corporate communication is an uneasy substance. Corporate communication strategies are needed for employee performance improvement, where the BHR Law Office implements communication strategies that emphasize messages distribution, both verbal and non-verbal communication.

Keywords: strategy, communication, employee performance.

\section{PENDAHULUAN}

Komunikasi adalah instrumen yang digunakan manusia dalam berinteraksi dengan sesama, di kehidupan sehari-hari ataupun dalam lingkungan kerja. Dalam lingkungan kerja komunikasi adalah alat yang memiliki fungsi sebagai penghubung serta penggerak motivasi antar sesama karyawan sehingga sebuah kantor dapat berjalan dengan baik. Proses komunikasi efektif ialah syarat terbinanya kerjasama yang baik untuk menggapai tujuan perusahaan. Komunikasi dalam sebuah lingkungan kerja merupakan unsur pokok selain tujuan perusahaan dan motivasi, 
begitu pula di dalam kantor konsultan hukum. Kantor konsultan hukum adalah suatu persekutuan perdata, yang terdiri dari dua atau lebih advokat yang melakukan praktek keadvokatan bersama yang mempunyai tugas menyediakan layanan jasa di bidang hukum kepada masyarakat.

Salah satu kantor konsultan hukum di Denpasar adalah BHR Law Office secara resmi berdiri pada tanggal 2 Januari 2014. Sejak berdiri, kantor konsultan hukum ini telah menyelesaikan banyak perkara perdata dan pidana, dalam hal mendampingi dan/atau mewakili klien sebagai penggugat, tergugat, pemohon, termohon, mendampingi tersangka dan membela terdakwa. Kantor konsultan hukum ini juga memberikan konsultasi hukum serta menangani perkara perdata dan pidana sebagai contoh warisan, wanprestasi, pertanahan, dan lain-lain.

Dalam menjalankan kegiatan perkantoran, BHR Law Office menghasilkan arsip dinamis sebagai hasil sertaan dari proses kegiatan sehari-hari. Menurut Cunningham, et all (2013), menyebutkan pada kantor konsultan hukum terdapat dua macam arsip dinamis, arsip administrasi dan arsip hukum. Arsip administrasi adalah arsip yang berhubungan dengan jalannya kegiatan bisnis kantor konsultan hukum. Sedangkan arsip hukum adalah arsip yang diciptakan dalam kaitannya dengan penerapan kaidah-kaidah hukum. Termasuk didalamnya adalah berkas perkara klien dan arsip produk penelitian hukum.

BHR Law Office menyadari pentingnya arsip dinamis sebagai bukti dari kegiatan dan kebijakan yang mereka lakukan. Kesadaran akan arti penting keberadaan arsip dilatarbelakangi oleh pertanggungjawaban tindakan kantor kepada klien. Arsip dinamis yang tercipta dalam proses kegiatan bisnis kantor BHR Law Office merupakan hasil sertaan. Hasil sertaan tersebut berupa informasi terekam yang menjadi bukti dari kegiatan yang dilakukan oleh kantor BHR Law Office. Kegunaannya menurut Sulistyo dan Basuki (2014), antara lain sebagai memori dalam berkas kantor, penggagas pengambilan keputusan oleh manajemen, pendorong litigasi serta sebagai arsip perusahaan.

Untuk terciptanya arsip dinamis di dalam BHR Law Office sendiri tidak terlepas dari proses koordinasi yang tentu saja melibatkan komunikasi. Komunikasi merupakan satu kegiatan yang tidak dapat dipisahkan dari sebuah perusahaan, begitu pula di BHR Law Office. Dalam menjalankan arsip dinamis BHR Law Office, sering terjadi miskomunikasi atau proses komunikasi yang terhambat antara pimpinan dengan karyawan, ataupun sesama karyawan. Salah satu miskomunikasi yang sering terjadi mengenai delegasikan tugas perkara klien dan mengenai informasi administrasi baik dari pimpinan dengan karyawan atau sebaliknya dan antara sesama karyawan.

Keberlangsungan hidup suatu perusahaan salah satu faktor menilai kinerja karyawan. Menurut Mangkunegara (2013), Kinerja karyawan ialah pencapaian hasil kerja secara kuantitas dan kualitas serta ketepatan waktu oleh seorang karyawan di dalam melaksanakan tugasnya sesuai dengan tanggung jawab yang diberikan. Salah satu menurunnya kinerja karyawan BHR Law Office yang disebabkan oleh miskomunikasi dibidang pengarsipan adalah pemberkasan yang kurang teratur yang mengakibatkan kesulitan klien untuk mengakses datanya.

Berdasarkan permasalahan latar belakang diatas Penelitian ini bertujuan untuk mengetahui "Strategi Komunikasi dalam meningkatkan kinerja karyawan di BHR Law Office". 


\section{KAJIAN LITERATUR}

\section{Strategi}

Menurut Griffin, M., et all (2014) Setiap organisasi pada dasarnya memiliki strategi-strategi tersendiri dalam memajukan organisasinya mulai dari strategi yang sederhana sampai pada strategi-strategi yang kompleks.

Aktivitas strategi pada setiap organisasi pada umumnya, usaha mengembangkan suatu kerjasama tim ataupun sekelompok orang di satu kesatuan dengan memanfaatkan sumberdaya manusia untuk mencapai tujuan tertentu dalam organisasi. Karena itu setiap bentuk organisasi dibentuk untuk mencapai tujuan, tentu memerlukan strategi. Strategi menurut Kamus Besar Bahasa Indonesia (KBBI) adalah cara untuk melaksanakan kebijakan tertentu guna mencapai suatu maksud. Jadi strategi adalah rangkaian keputusan dan ataupun tindakan guna mencapai tujuan organisasi.

Menurut Griffin, M., et all (2014) strategi memiliki beberapa tahapan-tahapan untuk mencapai tujuannya, antara lain:

a. Perencanaan

Perencanaan yang mencakup penetapan tujuan dan standar, penentuan dan prosedur, pembuatan rencana serta prediksi yang diperkirakan akan terjadi. Perencanaan merupakan proses menentukan tujuan yang ingin dicapai serta langkah-langkah yang digunakan untuk mencapainya. Lewat perencanaan, seorang manajer mengidentifikasikan hasil kinerja kerja serta mengidentifikasikan cara-cara untuk mencapai tujuannya.

b. Pengorganisasian

Pengorganisasian merupakan proses mendelegasikan tugas, pelokasian sumber daya, pengaturan kegiatan agar terkoordinasi kepada setiap individu dan kelompok guna menetapkan rencana. Fungsi pengorganisasian meliputi pemberian tugas yang terpisah kepada masing-masing karyawan, dan mendelegasikan, menetapkan alur suatu wewenang serta tanggung jawab dan system komunikasi, serta mengkoordinasikan kerja ksetiap karyawan didalam suatu tim kerja yang terorganisir. Pengorganisasian merupakan kelanjutan dari fungsi perencanaan dimana tujuan perusahaan ditetapkan dan sumberdaya manusia diarahkan untuk mencapai tujuannya.

c. Penyusunan Staff

Penyusunan Staff merupakan penentuan terhadap personel yang sedang dikerjakan, menarik dan memilih calon karyawan, menentukan deskripsi pekerjaan dan teknis suatu pekerjaan, penilaian dan pelatihan yang termasuk pengembangan kualitas serta kuantitas karyawan sebagai dasar setiap fungsi manajemen organisasi.

d. Pengarahan

Pengarahan merupakan kegiatan untuk memberikan semangat kepada karyawan agar bekerja secara tekun, dan membimbing karyawan melaksanakan rencana guna mencapai tujuan. Fungsi pengarahan yaitu mengarahkan orang lain melakukan pekerjaannya, mendorong, dan memotivasi, serta menciptakan suasana kerja yang kondusif, khususnya komunikasi keatas dan/ataupun sebaliknya, diharpakan timbulnya rasa saling pengertian dan juga kepercayaan yang baik.

e. Pengawasan

Fungsi pengawasan mencakup, persiapan suatu standarisasi kualitas dan kuantitas, hasil kerja dalam bidang jasa yang diberikan organisasi untuk upaya mencapai tujuan bersama. Dalam hubungan ini, fungsi pengawasan merupakan mengukur kinerja dan juga membandingkan antara hasil yang sesungguhnya dengan rencana dan mengambil tindakan pembetulan yang diperlukan. 


\section{Komunikasi}

Komunikasi merupakan salah satu yang kompleks bagi kehidupan manusia. Manusia mempengaruhi komunikasi yang dilakukannya dengan manusia lain, baik yang sudah dikenal maupun yang tidak dikenal sama sekali. Dalam Kamus Besar Bahasa Indonesia (KBBI) dijelaskan bahwa komunikasi ialah pengiriman dan juga penerima pesan dan/atau berita antara dua orang atau lebih sehingga pesan yang dimaksud dapat dipahami. Menurut Hardjana, sebagaimana dikutip oleh Lestari G. (2014) secara etimologis komunikasi berasal dari Bahasa Latin yaitu cum, sebuah kata depan yang artinya dengan, atau bersama dengan, dan kata umus, sebuah kata bilangan yang berarti satu. Dua kata tersebut menjadi kata benda communion, yang dalam bahasa Inggris disebut communion, yang memiliki arti kebersamaan, persatuan persekutuan, gabungan, pergaulan, atau hubungan. Karena untuk communio diperlukan usaha dan kerja, makan kata communion dijadikan kata kerja menjadi communicate dengan arti tukar menukar pikiran, memberitahukan sesuatu kepada seseorang, bertukar pikiran, berhubungan, atau berteman. Dengan demikian, komunikasi mempunyai makna pemberitahuan, pembicaraan, percakapan, pertukaran pikiran, atau hubungan. Sementara itu, Onong Uchjana dan Effendy (2013) mengemukakan bahwa komunikasi ialah proses ide dialihkan dari sumber yang satu ke sumber yang lain, dengan maksud mengubah tingkah laku seseorang. antara lain:

Menurut Onong Uchjana dan Effendy (2013) mengemukakan beberapa fungsi komunikasi

a. Menginformasikan (to inform)

Memberikan informasi untuk masyarakat, memberitahukan masyarakat mengenai peristiwa yang terjadi, pikiran dan tingkah laku orang lain, serta segala sesuatu yang akan disampaikan orang lain.

b. Mendidik (to educated)

Dengan komunikasi, manusia dapat menyampaikan pikirannya kepada orang lain, sehingga orang lain mendapatkan informasi dan ilmu pengetahuan juga.

c. Menghibur (to entertain)

Komunikasi juga berfungsi untuk menyampaikan hiburan atau menghibur orang lain.

d. Mempengaruhi (to influence)

Berusaha saling mempengaruhi dan lebih jauh lagi berusaha merubah sikap dan tingkah laku seseorang sesuai dengan yang diharapkan.

Dalam komunikasi setiap hari pesan yang disampaikan oleh pengirim kepada penerima dapat dilakukan melaui secara verbal dengan kata-kata ataupun non verbal tanpa kata-kata. Komunikasi yang pesannya dikemas secara verbal disebut komunikasi verbal, sedangkan komunikasi yang pesannya dikemas secara non verbal disebut komunikasi non verbal. Komunikasi verbal mengambil peran sebesar 65\% dan komunikasi non verbal sebesar $35 \%$ (Hardjana, 2013).

Menurut Hardjana (2013) komunikasi verbal ialah komunikasi yang menggunakan kata-kata, entah lisan maupun tulisan. Komunikasi ini paling banyak dipakai dalam hubungan antar manusia. Dalam komunikasi verbal bahasa memegang peranan penting. Komunikasi verbal memiliki karakteristik antara lain sebagai berikut:

a. Jelas dan Ringkas

Komunikasi berlangsung secara langsung, sederhana, pendek. Jika kata-kata digunakan sedikit, maka akan terjadi kerancuan antara para pihak. Berbicara dengan pengucapan yang jelas akan membuat tiap kata makin mudah dipahami.

b. Penggunaan kata

Menggunakan kata-kata yang mudah dimengerti oleh seorang akan meningkatkan efektivitas komunikasi. Komunikasi tidak akan berhasil jika pemberi pesan tidak mampu menerjemahkan kata atau ucapan. 
Menurut Hardjana (2013), komunikasi non verbal jauh lebih sering digunakan daripada komunikasi verbal. Saat berkomunikasi hampir tidak disadari komunikasi nonverbal ikut terpakai. Oleh sebab itu, komunikasi nonverbal memiliki sifat tetap dan selalu ada. Komunikasi nonverbal lebih jujur mengungkapkan dikarenakan spontanitas.

Menurut Gordon. I Zimmerman dan Davis (2014) tujuan dari komunikasi dibagi menjadi dua jenis antara lain manusia berkomunikasi untuk menyelesaikan tugas-tugas yang penting dan juga manusia berkomunikasi untuk menciptakan dan memupuk hubungan dengan manusia. Dari definisi diatas dapat dijelaskan bahwa tujuan komunikasi adalah kebutuhan manusia dan memupuk hubungan dengan manusia lain.

Menurut Cangara dan Hafied (2017) tujuan komunikasi pada umumnya mengandung halhal yang sebagai berikut:

a. Supaya yang disampaikan dapat dipahami

b. Memahami informasi atau pemahaman orang lain

c. Supaya gagasan dapat diterma oleh orang lain

d. Menggerakkan orang lain untuk mengerjakan sesuatu.

Menurut Widjaja (2012) tujuan komunikasi ialah penjelasan sesuatu hal kepada orang lain dan menerima dan mendukung informasi dan pemahaman dari orang lain. Tujuan komunikasi ialah agar orang lain mengerti dan mengerjakan sesuatu sesuai dengan tugas mereka.

Oleh karena itu, dibutuhkan strategi komunikasi yang baik untuk mencapai tujuan komunikasi. Menurut Onong Uchjana dan Effendy (2013) mendefinisikan strategi komunikasi sebagai paduan dari perencanaan komunikasi (communication planning) dan manajemen komunikasi (communication management) untuk mencapai suatu tujuan. Untuk mencapai tujuan, strategi komunikasi harus menunjukkan bagaimana operasionalnya secara efisien, dalam arti kata bahwa pendekatan bisa berbeda sewaktu-waktu tergantung dari situasi dan juga kondisi.

\section{Kinerja Karyawan}

Menurut Nitisemito dan Alex (2001) mendefinisikan kinerja (performance) sebagai hasil kerja yang dapat dicapai oleh seseorang atau kelompok orang dalam suatu organisasi sesuai wewenang dan tanggung jawab masing - masing, dalam rangka mencapai tujuan organisasi yang bersangkutan. Menurut Faustino dan Gomes (1995), kinerja karyawan ialah catatan hasil (outcomes) dari suatu fungsi pekerjaan tertentu atau kegiatan tertentu dalam suatu periode.

\section{METODE}

\section{Lokasi Penelitian}

Lokasi penelitian ini di BHR Law Office. Lokasi ini dipilih sebagai objek penelitian karena dalam menjalankan tugas arsip dinamis, BHR Law Office sering terjadi miskomunikasi atau proses komunikasi yang terhambat antara pimpinan dengan para karyawan atau antara sesama karyawan.

\section{Jenis Data}

Jenis data penelitian ini yaitu data kualitatif. Data kualitatif adalah informasi yang bersifat deskriptif seperti kata-kata, kalimat. Data kualitatif dalam penelitian ini adalah data yang tidak berupa angka-angka, melainkan berupa penjelasan atau keterangan yang mendukung penelitian ini seperti company profile BHR Law Office. 


\section{Sumber Data}

1. Data Primer

Sumber data penelitian ini terbagi menjadi 2 (dua) antara lain yaitu:

Data yang di lapangan dan dikumpulkan oleh peneliti dari sumber utamanya. Adapun sumber data primer penelitian ini, yaitu data pemberkasan arsip dinamis di BHR Law Office tahun 2018.

2. Data Sekunder

Data yang dikumpul peneliti sebagai data pendukung dari sumber utama. Data yang tersusun dalam bentuk dokumen-dokumen. Dalam penelitian ini, buku-buku mengenai pengarsipan merupakan sumber data sekunder.

\section{Teknik Pengumpulan Data}

Teknik pengumpulan data yang digunakan dalam penelitian ini, antara lain:

1. Observasi

Menurut Suharsimi dan Arikunto (2011) Observasi atau pengamatan, yaitu kegiatan pemantauan suatu objek yang menggunakan indera manusia. Metode ini digunakan oleh peneliti untuk mengetahui proses komunikasi dibidang arsip dinamis di BHR Law Office.

2. Dokumentasi

Teknik dokumentasi dipergunakan untuk melengkapi sekaligus menambah keakuratan, kebenaran data atau informasi yang dikumpulkan dari bahan-bahan dokumentasi di lapangan dijadikan bahan pengecekan keabsahan data.

3. Wawancara

Menurut Abdurrahman (2010), metode pengumpulan data dengan cara berkomunikasi langsung dengan responden. Wawancara ialah proses interaksi antara pewawancara dan para responden. Peneliti melakukan wawancara kepada pimpinan serta karyawan di BHR Law Office.

\section{Teknik Analisis Data}

Teknik analisis data yang dilakukan adalah deskriptif kualitatif. Analisis deskriptif kualitatif yang dimaksud adalah peneliti mengkaji data dari lapangan dengan cara mendeskripsikannya kedalam sebuah kata-kata atau kalimat. Analisis data yang dilakukan merupakan kumpulan dari hasil observasi, dokumentasi serta wawancara dan diproses melalui pencatatan dan akan dideskripsikan melalui sebuah kata-kata dan kalimat.

\section{PEMBAHASAN}

\section{Strategi Komunikasi dalam meningkatkan Kinerja Karyawan Di BHR Law Office}

Kegiatan bisnis yang dilakukan oleh kantor konsultan hukum yaitu memberikan konsultasi hukum bagi klien yang mencari keadilan, membela, mendampingi dan/atau mewakili klien dalam persidangan, serta melakukan persidangan di pengadilan.

Tindakan yang dilakukan dalam pengumpulan bukti-bukti antara lain meminta data-data klien, data perbankan atau surat permohonan barang bukti lain, kepada pihak yang berkepentingan. Konsultan hukum juga mengarsipkan surat-surat dari klien, kepolisian, pengadilan, bahkan dari media massa. Setiap tindakan-tindakan yang dilakukan akan menjadi arsip dinamis dalam sebuah kantor konsultan hukum.

Kesadaran akan arti penting keberadaan arsip dilatarbelakangi oleh pertanggungjawaban tindakan kantor kepada klien. Arsip dinamis yang tercipta dalam proses kegiatan bisnis kantor 
BHR Law Office merupakan hasil sertaan. Hasil sertaan tersebut berupa informasi terekam yang menjadi bukti dari kegiatan yang dilakukan oleh kantor BHR Law Office.

Arsip yang dilakukan oleh BHR Law Office tidak selalu sama pada setiap perkara-perkara hukum. Perkara pidana, tidak akan sama jenis arsip yang tercipta antara satu perkara pidana dengan perkara pidana lainnya, karena sifatnya kondisional pada tiap kasus. Namun bila kantor konsultan hukum menerima dan mengarsipkan arsip yang memiliki hubungan dengan proses penyelesaian suatu perkara, arsipnya harus dikembalikan kedalam berkas perkara.

Dalam proses pengarsipan sering terjadi miskomunikasi atau proses komunikasi yang terhambat antara pimpinan denga karyawan ataupun sesama karyawan. Salah satu miskomunikasi yang terjadi dalam BHR Law Office ialah pengarsipan berkas perkara perdata dan pidana pada tahun 2018. Pengarsipan berkas tahun 2018 mengalami ketidakrapian dalam merapikan arsip hukum 2018.

Pengarsipan berkas merupakan suatu tugas yang penting dikarenakan pertanggungjawaban pihak kantor kepada klien. Dokumen yang wajib ada di berkas perkara antara lain skema perkara, resume perkara, surat kuasa, dakwaan, eksepsi, putusan sela, replik, duplik, tuntutan, pledoi, putusan Pengadilan Negeri. Namun jika klien belum merasa hak hukumnya terpenuhi akan dilanjutkan dengan memori banding, putusan Pengadilan Tinggi., memori kasasi, putusan Mahkamah Agung. Hal tersebut telah sesuai dengan teori yang diungkapkan oleh Barata dan Kimberly (1999), yaitu perusahaan harus memiliki kebijakan dan prosedur dalam rangka mengolah arsip dinamis yang datang.

Terjadinya miskomunikasi atau proses komunikasi yang terhambat di BHR Law Office ialah penyampaian informasi mengenai tugas pengarsipan dari pimpinan kepada karyawan yang tidak tersampaikan dengan baik. Penyampaian informasi yang tidak tepat mengakibatkan pekerjaan yang dilaksanakan tidak mencapai tujuan. Kinerja karyawan juga dilihat dari proses pengarsipan berkas ini. Kinerja karyawan yang menurun juga dapat menjadi salah satu penyebab terjadinya miskomunikasi.

Menurut Onong Uchjana dan Effendy (2013), Komunikasi merupakan hal yang mengikat kesatuan organisasi. Komunikasi membantu para karyawan untuk mencapai tujuan, meresponkan dan mengimplementasikan perubahan perusahaan, mengkoordinasikan aktivitas perusahaan. Meskipun demikian, berkomunikasi dengan baik tidaklah mudah. Oleh karena itu, dibutuhkan strategi komunikasi yang baik untuk kinerja karyawan yang sebagai perencanaan komunikasi (communication planning) dan manajemen komunikasi (communication management) untuk mencapai suatu tujuan perusahaan (Onong Uchjana dan Effendy,2013).

Berdasarkan hasil wawancara dengan pimpinan dan karyawan BHR Law Office, adapun strategi komunikasi yang digunakan untuk meminimalkan misskomunikasi agar kinerja karyawan meningkat dalam pengarsipan dinamis adalah memperbaiki bentuk komunikasi dalam penyebaran pesan selama ini baik komunikasi verbal dan juga non verbal. Menurut Wayne dan Faules (2015), Penyebaran Pesan merupakan sesuatu yang ingin disampaikan komunikator kepada komunikan. Akan tetapi, ketika pesan tersebut disampaikan dari komunikator ke komunikan, pesan tersebut menjadi konkret. Pesan yang dilakukan dapat berupa komunikasi secara verbal antara pimpinan dan karyawan ataupun sesama karyawan. Komunikasi antar sesama karyawan biasanya mengenai tugas-tugas yang diberikan dimana setiap karyawan saling membantu satu sama lain mengenai tugas yang kurang dimengerti.

Informasi secara bersamaan kepada beberapa karyawan secara langsung yang disampaikan oleh seorang pimpinan cukup sering dilakukan karena mengingat penting nya sifat informasi tersebut. Di lain hal, komunikasi verbal untuk peningkatan kinerja karyawan BHR Law Office, dibentuk sistem yang memudahkan penyaluran informasi kepada semua karyawan dalam waktu yang bersamaan. Kegiatan yang dilakukan BHR Law Office untuk menyalurkan pesan secara serentak, yaitu: 
1. Rapat Rutin Bulanan

Setiap bulan minggu pertama BHR Law Office selalu mengadakan rapat rutin untuk mengevaluasi ataupun memberikan pekerjaan-pekerjaan yang harus diselesaikan selama satu bulan tersebut.

2. Kegiatan Informal Bulanan

Pada akhir bulan atau minggu keempat BHR Law Office juga mengadakan kegiatan makan-makan ataupun kumpul bersama antara pimpinan dengan semua karyawan, dan berbincang-bincang santai untuk memberikan motivasi bagi para karyawan guna meningkatkan kinerja kerja karyawan

3. Kegiatan Informal Tahunan

Pada bulan Desember BHR Law Office mengadakan kegiatan tutup tahun dan juga merapatkan kegiatan selama setahun terakhir serta mengevaluasi segala kegiatan selama setahun terakhir.

Dalam menyalurkan pesan tersebut BHR Law Office telah melakukan komunikasi verbal dengan menggunakan bahasa yang jelas dan ringkas serta pembendaharaan kalimat yang mudah dimengerti seseorang. Hal ini sesuai dengan Teori yang diungkapkan oleh Hardjana (2013) dimana komunikasi verbal memiliki ketiga karakteristik tersebut diatas.

Sedangkan pesan non verbal juga sangat mempengaruhi terhadap komunikasi. Dalam melakukan kegiatan pekerjaan BHR Law Office juga menggunakan komunikasi non verbal melalui, yaitu:

1. Email

Penggunaan email dalam BHR Law Office ialah untuk mengirimkan berkas-berkas kepada klien. Dan email digunakan untuk menjalankan persidangan secara online atau yang disebut dengan e-court. E-court ialah persidangan yang dilakukan secara online melalui web Mahkamah Agung, maka dari itu saat ini sidang di Pengadilan mulai dikurangi karena sudah adanya E-Court.

2. Surat Menyurat

Surat Menyurat yang dilakukan BHR Law Office biasanya untuk memenuhi syarat-syarat klien dalam sebuah perkara, ataupun surat menyurat dilakukan untuk melakukan mediasi di luar pengadilan kepada pihak-pihak yang bersengketa.

3. Sosial media seperti Grup Whatsapp Perusahaan

Sosial media Grup Whatsapp Perusahaan digunakan untuk berkomunikasi antara pimpinan dengan sesama karyawan, dan juga grup whatsapp perusahaan digunakan untuk memberikan informasi yang penting secara serentak sehingga seluruh anggota mengetahuinya secara bersamaan.

Proses komunikasi non verbal yang dilakukan biasanya mengenai pengarsipan berkas klien atau informasi dari klien mengenai perkara ataupun informasi dari pimpinan kepada karyawan mengenai tugas pengarsipan berkas dan juga komunikasi sesama karyawan mengenai menjalankan tugas-tugas yang telah diperintahkan. Komunikasi non verbal dapat memberikan penekanan terhadap informasi yang disampaikan secara verbal dari pimpinan kepada karyawan ataupun sesama karyawan sehingga miskomunikasi dapat diminimalkan serta menciptakan suasana kerja yang sehat. 


\section{SIMPULAN}

Berdasarkan pembahasan tersebut diatas, maka dapat ditarik kesimpulan yaitu strategi komunikasi pada BHR Law Office menitik beratkan kepada pesan, baik melalui komunikasi verbal dan komunikasi nonverbal. Dimana pesan menjadi produk komunikasi perusahaan melalui rapat rutin bulanan, rapat informal bulanan, serta rapat informal tahunan. Komunikasi non verbal yang digunakan ialah melalui Email, Surat Menyurat, dan juga melalui sosial media seperti Grup Whatsapp Perusahaan. Komunikasi non verbal dapat memberikan penekanan terhadap informasi yang disampaikan secara verbal dari pimpinan dengan karyawan ataupun sesama karyawan sehingga miskomunikasi dapat diminimalkan serta menciptakan iklim kerja yang sehat.

\section{REFERENSI}

Kamus Besar Bahasa Indonesia. [Online]. Tersedia di kbbi.kemdikbud.go.id. Diakses 17 Januari 2020

Abdurrahman. 2010. Metode Penelitian Komunikasi. Bandung: PT. Remaja Rosdakarya.

Barata dan Kimberly. 1999. "Managing public sector records: a study programme "understanding computers: an overview for records and archives staff". London, United Kingdom: International Records Management Trust.

Cangara dan Hafied. 2017. Perencanaan \& Strategi Komunikasi, edisi Revisi, Jakarta: PT. Raja Graffindo Persada.

Cunningham F.G., Leveno, K.J., Bloom, Hauth, J.C. Williams. 2013. Obstetri Williams. Cetakan 23, Jakarta: EGC.

Faustino Cardoso dan Gomez. 1995. Manajemen Sumber Daya Manusia. Jakarta: Andi Offset.

Gordon I Zimmerman dan Davis. 2014. Kerangka Dasar Sistem Informasi Manajemen. Palembang: Maxikom

Griffin, Ricky W, Moorhead, Gregory. 2014. Organizational Behavior: Managing People and Organizations. Eleventh Edition. USA: South Western.

Hardjana, Agus M. 2013. Komunikasi intrapersonal \& Komunikasi Interpersonal. Yogyakarta: Penerbit Kanisius.

Lestari G. Endang. 2014. Komunikasi yang Efektif. Jakarta: Lembaga Administrasi Negara.

Mangkunegara, AP. 2013. Perencanaan dan Pengembangan Sumber Daya Manusia. Bandung: Rfika Aditama.

Nitisemito dan Alex. 2001. Manajemen Personalia. Jakarta: Ghalia Indonesia.

Onong Uchjana dan Effendy. 2013. Ilmu Teori dan Filsafat Komunikasi, Bandung: Citra Aditya Bakti.

Onong Uchjana dan Effendy. 2013. Ilmu Komunikasi, Teori dan Praktek. Bandung: PT. Remaja Rosdakarya.

Suharsimi dan Arikunto. 2011. Prosedur Penelitian: Suatu Pendekatan Praktik. Edisi Revisi VII. Jakarta: PT. Rineka Cipta. 
Sulistyo dan Basuki. 2014. Metode Penelitian. Jakarta: Wedatama Widya Sastra.

Wayne. Pace. R, Don F, Faules. 2015. Komunikasi Organisasi: Strategi Meningkatkan Kinerja Perusahaan. Bandung: PT. Remaja Rosdakarya.

Widjaja, A.W. 2012. Komunikasi dan Hubungan Masyarakat. Jakarta: PT. Bumi Aksara. 